\title{
Impact of Structured Water on Yield and Crop Quality of Radish (Raphanus sativus L.)
}

\author{
Mirosław Gluch ${ }^{1}$, Jacek Gronek ${ }^{1}$, Jan Karch', \\ Andrzej Skrobiszewski ${ }^{1}$, Piotr Chohura ${ }^{2 *}$ \\ ${ }^{1}$ Hydreset AG, Alti Luzeinerstrass 2, 7240 Küblis 6, Switzerland \\ ${ }^{2}$ Department of Horticulture, The Faculty of Life Sciences and Technology, Wroclaw University of Environmental \\ and Life Sciences; Grunwaldzki Sq. 24A, 50-363 Wrocław, Poland
}

Received: 3 October 2020

Accepted: 18 December 2020

\begin{abstract}
In the field experiment, radish was grown in the spring cycle and was watered with two types of water. Tap water (control) and structured water were used for irrigation. The use of structured water for radish irrigation contributed significantly to increase the yield in radish roots compared to the tap water. Radish watered with structured water contained more photosynthetic pigments and carotenoids compared to the control. The vitamin $\mathrm{C}$ content in radish leaves and roots was higher when tap water was used for irrigation, while nitrates level was lower after structured water using. The use of different types of water for radish watering had no significant effect on the concentration of minerals in the roots. The research confirmed the beneficial effect of structured water on the yield and the quality of the radish and revealed the possibility of using it for plants irrigation.
\end{abstract}

Keywords: structured water, radish, Raphanus sativus, vegetable crops, yield

\section{Introduction}

Water is essential for all human beings due to its significant and complex role in life processes such as activities of enzyme apparatus and responses of cells to various signals [1]. Some papers showed that structured water elongated clusters and their mutual interplays [2] could play an essential role in altering the physicochemical parameters of water [3], resulting for instance in the reduction of early-age concrete cracking [4]. Furthermore, according to Dubey et al. [5] structured water not only helps to increase the crop

*e-mail: piotr.chohura@upwr.edu.pl yield, but also enhances productivity and fertility in some animal breedings. Nevertheless, the effect and the role of structured water in agriculture and other branches of industry are still need to be proven.

Vegetables are valuable ingredients in human's diet, rich in vitamins, minerals and precious substances [6]. There are around 250 species of vegetables well-known in the world, among which 40 are grown in Poland, which is one of the leading vegetables producers in the European Union. In the years 2004-2017 annual domestic production of vegetables in Poland was between 4.8 and 5.7 million tons, which represents around 9\% production of vegetables in the EU [7].

Radish (Raphanus sativus) belongs to the Brassicaceae family and contains minerals (Fe, $\mathrm{Ca}, \mathrm{Mg}$, $\mathrm{Cu}, \mathrm{Mn})$ and vitamin $\mathrm{C}[8,9]$. According to Kopta et 
al. [10] due to the nutritional value, this vegetable can improve digestive process. Equally important, radish is characterized by short growing period and can be cultivated both in the field and under protected area [11].

With regard to these reports, we have decided to take up research on the assessment of the effect of structured water produced by Hydreset AG on yield and crop quality of radish.

\section{Material and Methods}

Field experiment regarding radish cultivation was conducted in the spring season 2020 at Lower Silesia, Poland in 2020. It was established as one - factorial experiment in three replications. Structured water was produced by Hydreset AG. Radish seeds Wernar F1 cv. were sown on $2^{\text {nd }}$ May on plots measuring $1.0 \times 1.2$ $\mathrm{m}$, in the amount of $3.5 \mathrm{~g} \cdot \mathrm{m}^{-2}$. Spacing between rows equaled $15 \mathrm{~cm}$. After germination the seedlings were thinned to keep the distance of $2.5 \mathrm{~cm}$ between the plants in the rows. Plants were watered with tap water and structured water. Spring 2020 was with a shortage of rainfall and before starting the research, the soil was very dry. Immediately before sowing the seeds, soil was watered with two types of water. The irrigation dose was $20 \mathrm{~mm}$. In order to eliminate the influence of the rainfall, plots irrigated with structured water were covered with plastic foil. Radish was harvested, when most of the roots reached the diameter over $2.0 \mathrm{~cm}$ on $9^{\text {th }}$ June. The nutrient content in soil was adjusted to the optimal level for the radish: In $\left[\mathrm{mg}^{-\mathrm{dm}^{-3}}\right]$ : $72 \mathrm{~N}^{-\mathrm{NO}_{3}}, 22 \mathrm{~N}^{-\mathrm{NH}_{4}}, 67 \mathrm{P}, 156 \mathrm{~K}, 92 \mathrm{Mg}, 892 \mathrm{Ca}$ and the remaining components maintained the level meeting radish nutritional requirements, $\mathrm{pH} 6.5$ and organic matter $2.1 \%$. The weather conditions were favorable for the development of radish, the temperature during the day was $14-18^{\circ} \mathrm{C}$ and at night $9-14^{\circ} \mathrm{C}$. Qualitative analysis of radish consisted in determination of nitrates content according to potentiometric method with the use of Orion electrode, dry matter content (after drying at $105^{\circ} \mathrm{C}$ to constant weight) and vitamin $\mathrm{C}$ (Tillman's method). In the leaves the content of chlorophylls, carotenoids (spectrophotometrically analyzed) and vitamin $\mathrm{C}$ were analyzed. The total content of minerals (P, K, Ca, Mg, Fe, Mn, Zn, Cu, B) was determined by ICP method, nitrogen levels by Kjeldahl method. The roots were sorted into fractions and then both measured and weighed. The results were subjected to statistical analysis and the least significant differences calculated by the Tukey's test at $\alpha=0.05$.

\section{Results and Discussion}

The average total yield of radish was $183.97 \mathrm{dt} \cdot \mathrm{ha}^{-1}$ and the marketable one $-162.20 \mathrm{dt} \cdot \mathrm{ha}^{-1}$ (Table 1). The radish yield depended on the type of water used for irrigation. Significantly higher total yield $-194.83 \mathrm{dt} \cdot \mathrm{ha}^{-1}$ was obtained after using structured water for irrigation in comparison to the tap water $-173.10 \mathrm{dt} \cdot \mathrm{ha}^{-1}$. A similar situation occurred in the case of the marketable yield. It was significantly higher by $33.88 \mathrm{dt} \cdot \mathrm{ha}^{-1}(18,9 \%)$ in the object watered with structured water in comparison to the tap water. A different situation occurred in the case of the unmarketable yield, which was significantly higher from the object irrigated with tap water.

Our research showed similar yielding data for Zia ul Haq et al. [12], who noted the positive influence of the magnetic field on radish emergence and yield. Similar results reported Umar et al. [13]. The yield obtained in our own research was higher than that given by Chohura and Kołota [11]. In turn Ptok [14] also reported on the positive effect of structured water on the lawn, radish sprout and Japanese mustard plant growth. As reported by Dubey et al. [5] the structured water has been found to increase the crop yield for example of the winter wheat $(28 \%)$, corn $(17 \%)$, cucumber $(32 \%)$ and tomato $(32 \%)$. This positive results were confirmed in our research.

Apart from the yield size, its quality is of the same importance. Is very important to maintain a proper nitrates level which should not exceed 1500 mg $\mathrm{NO}_{3} \mathrm{~kg}^{-1}$ of fresh matter [15]. The roots of radish irrigated with structured water had significantly lower concentration of nitrates compared to the control (Table 2). According to Kozik and Glen [16]. nitrates content in plants is strictly related to the dose and form of nitrogen applied. In our investigation it was not confirmed by the results. The higher amounts of those compounds were found in radish roots grown using the control treatment. Probably due to the higher yield in the plants irrigated with structured water, there was a dilution of nitrates and more nitrogen was accumulated in the protein. In Sady's opinion [17] nitrogen dose is one of the basic factors affecting nitrates content in vegetables, which was not proved in our experiments.

Table 1 . Yield of radish irrigated by different types of water $\left[\mathrm{dt} \cdot \mathrm{ha}^{-1}\right]$.

\begin{tabular}{|c|c|c|c|}
\hline Yield fraction & Tap water & Structured water & Mean \\
\hline Total yield & $173.10 \mathrm{~b}^{*}$ & $194.83 \mathrm{a}$ & 162.97 \\
\hline Marketable yield & $145.26 \mathrm{~b}$ & $179.14 \mathrm{a}$ & 21.21 \\
\hline Unmarketable yield & $26.72 \mathrm{a}$ & $15.69 \mathrm{~b}$ \\
\hline
\end{tabular}

*means in lines marked with the same letters do not differ significantly at $\alpha=0.05$. 
The average dry matter content in radish roots was $5.50 \%$ and did not differ significantly. In turn, the content of vitamin $\mathrm{C}$ was significantly higher in the roots of radish irrigated with tap water. Similar content of vitamin C was recorded by Andaleeb et al. [18], who noted that the content of vitamin $\mathrm{C}$ in the radish root decreased with increasing the roots weight. There seems to be a negative correlation between these features. On the other hand, Aboyeji [19] noted much smaller amounts of vitamin $\mathrm{C}$ in radish.

The content of carotenoids and chlorophyll in the leaves were determined. Generally, radish watered with structured water contained more photosynthetic pigments, with the exception of chlorophyll $b$, where the differences were not significant. It indicates better intake of nutrients and more efficient metabolism. As in the case of roots, the content of vitamin $\mathrm{C}$ in leaves was significantly higher in the plants watered with tap water.
The type of water used for irrigation had a significant impact on the yield of individual size fractions of roots. In the case of very large (diameter $>3.5 \mathrm{~cm}$ ) roots, a significantly higher yield was collected from the object watered with tap water (Table 3 ). In the case of the roots of the fraction from 2 to $3.5 \mathrm{~cm}$, significantly higher yields were obtained from the object watered with structured water.

The analysis of the percentage composition of the yield of radish roots generally confirmed the tendencies shown in Table 3. Only in the case of the size fraction 3-3.5 and 2-2.5, the differences were not significant

The content of minerals in radish roots was not significantly differentiated due to the applied water tape, except for boron (Table 5). Radish watered with structured water contained significantly more of this element. The contents of individual macro- and

Table 2. Crop quality of radish watered by tap water and structured water.

\begin{tabular}{|c|c|c|c|}
\hline Analyzed compounds & Tap water & Structured water & Mean \\
\hline \multicolumn{4}{|c|}{ Roots } \\
\hline Dry matter content in roots [\%] & $5.52 \mathrm{a}^{*}$ & $5.48 \mathrm{a}$ & 5.50 \\
\hline Nitrates content in roots $\left[\mathrm{mg} \mathrm{NO}_{3}^{-} \cdot \mathrm{kg}^{-1}\right.$ f.m. $]$ & $652.3 \mathrm{a}$ & $578.9 b$ & \\
\hline Vitamin C [mg. $100 \mathrm{~g}^{-1}$ f.m.] & $36.91 \mathrm{a}$ & $30.82 b$ & \\
\hline \multicolumn{4}{|c|}{ Leaves } \\
\hline Carotenoids content $\left[\mu \mathrm{g} \cdot \mathrm{g}^{-1}\right.$ f.m. $]$ & $1.95 b$ & $2.05 \mathrm{a}$ & \\
\hline Chlorophyll a [mg.g-1 f.m.] & $0.71 \mathrm{~b}$ & $0.75 \mathrm{a}$ & \\
\hline Chlorophyll b [mg.g-1 f.m.] & $0.22 \mathrm{a}$ & $0.23 \mathrm{a}$ & \\
\hline Chlorophyll a+b [mg $\cdot \mathrm{g}^{-1}$ f.m.] & $0.93 b$ & $1.00 \mathrm{a}$ & \\
\hline Vitamin C [mg. $100 \mathrm{~g}^{-1}$ f.m.] & $90.64 a$ & $73.24 b$ & \\
\hline
\end{tabular}

$*_{\text {see Table } 1}$

Table 3. Yield structure in terms of radish root size under different watering condition [dt $\left.\cdot h a^{-1}\right]$.

\begin{tabular}{|c|c|c|c|c|c|}
\hline \multirow{2}{*}{ Type of water } & \multicolumn{5}{|c|}{ Roots diameter [cm] } \\
\cline { 2 - 6 } & $>3.5$ & $3-3.5$ & $2.5-3$ & $2-2.5$ & $<2.0$ \\
\hline Tap water & $4.59 \mathrm{a}^{*}$ & $56.05 \mathrm{~b}$ & $45.02 \mathrm{~b}$ & $40.73 \mathrm{~b}$ & $26.72 \mathrm{a}$ \\
\hline Structured water & $3.09 \mathrm{~b}$ & $61.84 \mathrm{a}$ & $61.74 \mathrm{a}$ & $52.47 \mathrm{a}$ & $15.69 \mathrm{~b}$ \\
\hline
\end{tabular}

*means in columns marked with the same letters do not differ significantly at $\alpha=0.05$.

Table 4. Part of individual fraction in the total yield of radish irrigated of tap water and structured water [\%].

\begin{tabular}{|c|c|c|c|c|c|}
\hline \multirow{2}{*}{ Type of water } & \multicolumn{5}{|c|}{ Roots diameter $[\mathrm{cm}]$} \\
\cline { 2 - 6 } & $>3,5$ & $3-3,5$ & $2,5-3$ & $2-2,5$ & $<2,0$ \\
\hline Tap water & $2.65 \mathrm{a}^{*}$ & $32.39 \mathrm{a}$ & $26.01 \mathrm{~b}$ & $23.53 \mathrm{a}$ & $15.43 \mathrm{a}$ \\
\hline Structured water & $1.59 \mathrm{~b}$ & $31.74 \mathrm{a}$ & $31.70 \mathrm{a}$ & $26.94 \mathrm{a}$ & $8.03 \mathrm{~b}$ \\
\hline
\end{tabular}

\footnotetext{
*see Table 3.
} 
Table 5. Mineral content in radish watered by tap water and structured water.

\begin{tabular}{|c|c|c|c|}
\hline Element & Tap water & $\begin{array}{c}\text { Structured } \\
\text { water }\end{array}$ & Mean \\
\hline \multicolumn{4}{|c|}{$\mathrm{mg} \cdot 100 \mathrm{~g}^{-1} \mathrm{DM}$} \\
\hline $\mathrm{N}$ & $2450 \mathrm{a}$ & $2365 \mathrm{a}$ & 2408 \\
\hline $\mathrm{P}$ & $565 \mathrm{a}$ & $521 \mathrm{a}$ & 543 \\
\hline $\mathrm{K}$ & $3870 \mathrm{a}$ & $3792 \mathrm{a}$ & 3831 \\
\hline $\mathrm{Ca}$ & $154 \mathrm{a}$ & $148 \mathrm{a}$ & 151 \\
\hline $\mathrm{Mg}$ & $215 \mathrm{a}$ & $226 \mathrm{a}$ & 221 \\
\hline \multicolumn{5}{|c|}{$\mathrm{mg} \cdot \mathrm{kg}^{-1} \mathrm{DM}$} & 169.5 \\
\hline $\mathrm{Fe}$ & $165 \mathrm{a}$ & $174 \mathrm{a}$ & 70.0 \\
\hline $\mathrm{Mn}$ & $68 \mathrm{a}$ & $72 \mathrm{a}$ & 25.0 \\
\hline $\mathrm{Zn}$ & $26 \mathrm{a}$ & $24 \mathrm{a}$ & 7.9 \\
\hline $\mathrm{Cu}$ & $7.6 \mathrm{a}$ & $8.1 \mathrm{a}$ & 5.7 \\
\hline $\mathrm{B}$ & $5.1 \mathrm{a}$ & $6.2 \mathrm{~b}$ &
\end{tabular}

micronutrients were typical for radishes and confirmed the information provided by Goyeneche et al. [20].

\section{Conclusions}

1. The use of structured water for radish watering resulted in a significant increase on the total and marketable radish roots yields as compared to tap water.

2. Radish watered with structured water contained more chlorophyll and carotenoids compared to the control.

3. The vitamin $\mathrm{C}$ content in radish leaves and roots was higher when tap water was used for irrigation.

4. The nitrate content in radish roots was lower when structured water was used.

5. Type of water used for radish watering had no significant effect on the concentration of minerals in the roots. The elemental levels were at the typical levels for radish.

6 The research confirmed the possibility of using structured water on the yield, and the quality of radish.

\section{Conflict of Interest}

The authors declare no conflict of interest.

\section{References}

1. CHEN C-S., CHUNG W-J., HSU I.C., WU C-M., CHIN $\mathrm{W}-\mathrm{C}$. Force field measurements within the exclusion zone of water, J. Biol. Phys. 38, 113, 2012.
2. RAI S., SHARMA S., RAI D. Structured water chains in external electric fields. Mol. Phys. 1362-3028, 1, 2019.

3. WANG Y., WEI H., LI Z. Effect of magnetic field on the physical properties of water. Results. Phys. 8, 262, 2018.

4. WEI H., WANG Y., LUO J. Influence of magnetic water on early-age shrinkage cracking of concrete. Constr. Build. Mater. 147, 91, 2017.

5. DUBEY P.K., NEETHU T.M., KASWALA A.R. Structured water: an exciting new field in water science. Int. J. Agric. 10 (11), 6346, 2018.

6. CARCIU G.H., LAZUREANU A., ALDA S., MANEA D., BĂLUȚĂ D., DANCI M., NEGREA M., BUZATU C., MOTROC P. Impact of fertilization on yield in garden beet, cucumbers, celery, radish and spring onion. J. Hortic. Sci. Biotechnol. Volume 13, 344, 2009.

7. Krajowy Ośrodek Wsparcia Rolnictwa. Rynek warzyw w Polsce; KOWR: ul. Karolkowa 30, 01-207 Warszawa, Polska, ISBN 978-83-66255-01-2, 2018.

8. MAHMOUD A.W.M., ABDELAZIZ S.M., EL-MOGY M.M., ABDELDAYM E.A. Effect of foliar $\mathrm{ZnO}$ and $\mathrm{FeO}$ nanoparticles application on growth and nutritional quality of red radish and assessment of their accumulation on human health. Agr. (Pol'nohospodárstvo). 65 (1), 16, 2019.

9. BARAN A., JASIEWICZ C. Zawartość wybranych składników mineralnych $\mathrm{w}$ rzodkiewce zakupionej na placach targowych Krakowa. Bromat. Chem. Toksykol. XLIV (1), 25, 2011.

10. KOPTA T., POKLUDA R. Yields, quality and nutritional parameters of radish (Raphanus sativus) cultivars when grown organically in the Czech Republic. Hort. Sci. (Prague) Volume 40 (1), 16, 2013.

11. CHOHURA P., KOŁOTA E. The effect of nitrogen fertilization on radish yielding. Acta Sci. Pol., Hortorum Cultus. 10 (1), 23, 2011.

12. ZIA UL HAQ, JAMIL Y., IRUM S., RANDHAWA M.A., IQBAL M., AMIN N. Enhancement in Germination, Seedling Growth and Yield of Radish (Raphanus sativus) Using Seed Pre-Sowing Magnetic Field Treatment. Pol. J. Environ. Stud. Volume 21, No. 2 (2012), 369, 2011.

13. UMAR U.M., IRO I., OBIDOLA S.M. Growth and Yield of Radish (Raphanus sativus L.) as influenced by different levels of kalli organic fertilizer on the Jos Plateau. Asian J. Crop

14. PTOK F.L. Alternative Irrigation Methods: Structured Water in the context of a Growing Global Food Crisis due to Water Shortages. Undergraduate Honors Theses. 182. Available online: https://scholar.colorado.edu/honr theses/182 (accessed on 13 September 2020), 1, 2014.

15. Commission regulation (EC) No $1822 / 2005$ of 8 November 2005 amending Regulation (EC) No 466/2001 as regards nitrate in certain vegetables. OJ L 293, 9.11.2005, p. 11-13.

16. KOZIK E., GLEŃ B. The influence of nitrogen level and form on the content of nitrates in lettuce. Conference. Science for Horticulture Practice, AR Lublin: 699, 1995.

17. SADY W. Nawożenie warzyw polowych. Wyd. Plantpress, Kraków, 2006.

18. ANDALEEB A., IKHTIAR K., ABID M., ABDUL H. Yield, chemical composition and nutritional quality responses of carrot, radish and turnip to elevated atmospheric carbon dioxide. J. Sci. Food Agric. 93, 3237, 2013.

19. ABOYEJI C.M. 2019. Impact of green manures of Vernonia amygdalina and Chromolaena odorata on growth, yield, mineral and proximate composition of Radish (Raphanus sativus L.). Sci. Rep. 9, 17659, 2019. 
20. GOYENECHE R., ROURA S., PONCE A., VEGAGÁLVEZ A., QUISPE-FUENTES I., URIBE E., DI SCALA K. Chemical characterization and antioxidant capacity of red radish (Raphanus sativus L.) leaves and roots. J. Funct. Foods. 16, 256, 2015. 